Wien klin Mag 2021 $24: 43$

https://doi.org/10.1007/s00740-021-00393-1

Angenommen: 2. März 2021

(c) Springer-Verlag GmbH Austria, ein Teil von Springer Nature 2021

Verena Kienast

SpringerMedizin, Wien, Österreich

\title{
Richtig gut gemacht
}

\section{Die Corona-Teststrategie in Österreich als einsamer Erfolgsschritt}

Schulen Schutz vor dem Corona-Virus bieten könnten. Die Laborärzte warnten umgehend, dass nur PCR-Tests wirklich Sicherheit geben könnten und offiziell wurde festgehalten, dass anlassloses, sporadisches Testen nicht hilfreich sei. Die Corona-Virus-Testverordnung in Deutschland vom 27. Jänner 2021 zeigt akribisch auf, wer, wann, wie oft unter welchen Umständen getestet werden darf. Ursprünglich sollten kostenlose Antigentests in größerem Ausmaß ab 1. März angeboten werden, allerdings verschob sich wegen zahlreicher ungelöster Fragen der Beginn dieses Projekts auf unbestimmte Zeit. Nun versucht man, mehr Klarheit über die Schiene der Selbsttests zu ermöglichen. Was bei uns als „Nasenbohrertest" bereits in den Schulalltag und in den privaten Bereich eingezogen ist, läuft in Deutschland als „Popeltest“ und die ersten drei derartigen Produkte, von denen eines übrigens aus Graz stammt, wurden dort nun Ende Februar zugelassen. Man wird sehen.

\section{Müde Folgeschritte}

Die Anerkennung aus Deutschland, wo man mit der Impfung schneller, aber in der Öffentlichkeit auch nicht viel zufriedener damit ist, ist freilich kein Ruhekissen, auf dem man sich symbolisch lorbeergeschmückt ausruhen könnte. Obwohl dies den meisten Beteiligten durchaus klar ist, sind die Folgeschritte aus diesem strategischen Erfolg nach wie vor etwas müde bis unambitioniert. Nach wie vor werden, wie in vielen anderen Bereichen, gerade im Gesundheitswesen die gesammelten Daten nicht systematisiert und sinnvoll verknüpft, sodass tatsächlich ein aussagekräftiges
Bild des Geschehens - in diesem Fall der Infektionen - in Beziehung zu soziodemografischen Parametern gezeichnet werden könnte. Wer, wann, wo, in welchem Zusammenhang, unter welchen Umständen und mit welchen Folgen sich ansteckt, erkrankt und wieder gesund wird - oder auch nicht: Danach fragen selbst Experten großteils erfolglos. Das trägt auch zur öffentlichen Ungewissheit und Müdigkeit bei, und es lässt die Freude über das erfolgreiche Projekt der Corona-Tests bedauerlicherweise etwas einsam dastehen, meint Ihre

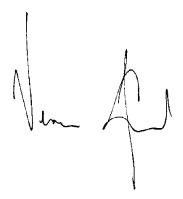

\section{Korrespondenzadresse}

Verena Kienast

SpringerMedizin

Wien, Österreich

Verena.kienast@springer.at

Hinweis des Verlags. Der Verlag bleibt in Hinblick auf geografische Zuordnungen und Gebietsbezeichnungen in veröffentlichten Karten und Instituts adressen neutral. 